\title{
Involvement of Persons with Physical Disabilities (PWD) in Technical Skills Field Employment
}

\author{
Jamil Abd Baser, Azman Hasan, Suhairi Ismail, Siti \\ Khadijah Omar, Nor Atikah Md. Jizat \\ Universiti Tun Hussein Onn Malaysia \\ Malaysia \\ jamil@uthm.edu.my
}

\author{
Moh. Khairudin \\ Faculty of Engineering, Universitas Negeri Yogyakarta \\ Yogyakarta, Indonesia \\ khairudin@uny.ac.id
}

\begin{abstract}
The purpose of this study were: (i) to identify dominant factors that drive the involvement of the person with physical disability in the technical and vocational skills employment; (ii) to identify the most dominant internal factor that prevents the involvement of the person with physical disability in the technical and vocational skills employment; (iii) to identify the most dominant external factor that prevents the involvement of the person with physical disability in the technical and vocational skills employment; and (iv) to identify the differences in the perception between genders in the involvement of the person with physical disability in the technical and vocational skills employment. This study was a descriptive survey study using Likert scale questionnaire as the instrument. The samples of the study were physical PWD trainees at the Bangi Industrial Training and Rehabilitation Centre for the disabled, which consists of 67 respondents. The collected data was analysed using Winsteps 3.69.1.11 software with the approach of Rasch Measurement Model. The finding from the analysis showed that the dominant factor that drives the involvement of physical PWD was employment. Work experience was the most dominant internal factor that prevents the involvement of the disabled in employment, while the employer was the most dominant external factor that prevents their involvement. The analysis found an insignificant difference in the perception between genders on their involvement in the technical and vocational skills employment.
\end{abstract}

Keywords-people with physical disabilities, employment, technical and vocational skills

\section{INTRODUCTION}

Persons with disabilities (PWD) is defined as a person who suffers from the limitations of movement whether in physical, mental, eyesight or hearing [1]. According to [2], disabled persons are defined as individuals who are not capable of determining their own needs or not be able to live as a community fully due to lack of either physically or mentally and need help from others to continue their lives. The [3] had categorized seven types of disability which are hearing, visually impaired, physical disabilities, speech disabilities, learning problems, mental disabilities and multiple disabilities.

The Malaysian Government has implemented the policy of one percent of job opportunity in the public service to Person with Disabilities (PWD) with aims to help those who qualified for a position in the public service [4]. Based on tracer study report by [5], a total of 384 persons with the percentage of $59.9 \%$ of graduates with disabilities who register could obtain full-time and part-time employment after graduation while $0.8 \%$ of them still waiting for job placement date. A total of $10.7 \%$ of the respondents decide to pursue the study. In addition, $29.0 \%$ disabled persons were reported still not working. The rate of working is highest for those studying master with the percentage of $100.0 \%$, while the highest rate of unemployed for those studying certificate level which is $40.0 \%$.

The organization of Educational, United Nations, Scientific and Cultural Organization (UNESCO) urged all parties to carry out inclusive education policy by registering special needs students in regular schools. The Government's efforts in safeguarding the disabled welfare in Malaysia arguably is better than other third countries. For example, in Nepal the provision of vocational training to this group still at minimal levels. This is due to Nepal's Government still lack of knowledge regarding the development of less fortunate people and don't have an appropriate vocational training curriculum to provide a comprehensive program [6].

\section{PRoBlem BACKGROUND}

According [7], to face the era of globalization and brilliance fast, every workforce is very important to face the ability to work from aspects of hard skills and soft skills in their field. Therefore, Physical and mental ability, soft skills, technical skills and qualifications serve as major factor selection by the employer these days in employing workers. Academic performance and workability skills are some of the most important elements that can help special groups to obtain occupation [8]. According to [9], the employer has difficulties to accept this group because they had no work experience and low skill level. This is supported by [1] who said that employers are still afraid and not confidence for accepting Person with Disabilities (PWD) as employees even if they had positive attitude, more focused on work, easily educated and never cheat on working hours. Vacancy opportunity also sometimes does not meet the skills possessed by them. In addition, the skills acquired in training institution is not in line 
with current market cause difficulties for them to obtain occupation.

According to the statistics issued by the [10], the number of disabled persons registered in Malaysia is about 359, 203 people. Statistics issued by the Labour Department Peninsular of Malaysia in 2012 showed 312 job seekers are from disabled people while the employer registration to employ them only as many as 70 people. This scenario clearly shows lack of involvement of Persons with Disabilities (PWD) in Malaysia's employment. Other than that, the less fortunate person comprising of $10 \%$ of the population in the world while $20 \%$ of them are poor clusters [6]. This is supported by the [11] which said that person with Disabilities (PWD) is $1 / 5$ of the world's poorest. [12] said that poverty occurs mostly due to isolation and marginalization factors on them by society starting from education until realm of employment.

Therefore, there are several key factors that cause a lack of involvement of Persons with Physical Disabilities (PWD) in technical and vocational skills employment. These factors are divided into two that are factors to motivate and factors that hinder their participation. Among the factors that led to those less fortunate to engage in employment is financial security, need to socialize and desire to get appreciation. Factors that hinder the participation of this group to be involved in the working world on the other hand also due to some external and internal factors. Among them is the attitude of parents and family, their own attitude, personality and employers still pessimistic for accepting them as an employee.

\section{OBJECTIVES}

Objectives of this paper are: (1) Identify the dominant factor that drives the involvement of Person with physical Disabilities (PWD) in technical and vocational skills employment, (2) Identify the most dominant internal factors that prevent the participation of Person with physical Disabilities (PWD) in technical and vocational skills employment, (3) Identify the most dominant external factors that prevent the participation of Person with physical Disabilities (PWD) in technical and vocational skills employment, and (4) Identify the differences between perception of ender against the involvement of Person with physical Disabilities (PWD) in technical and vocational skills employment.

\section{LITERATURE REVIEW}

A person with Disabilities (PWD) defined as those who have lacked in terms of long-term physical, mental, intellectual or sensory when interacting with various obstacles, can block their full and effective participation in society. This group is divided into two general categories that are permanent and temporary disabilities. The category of permanent disability is handicapped, hearing impaired, blind and elderly. Temporary disabilities category consists of individuals who are injured or sick in a certain length of time and the pregnant woman.
Types of disability for those with less fortunate influence employment status among their graduates [5]. Those experiencing a physical inability to work recorded at the medium level which is $55.4 \%$, followed by the inability of the sight with $60.9 \%$ and the inability of speech with $55.4 \%$. The highest working rate recorded among Persons with Disabilities (PWD) who suffer from numerous of disability that is $63.4 \%$ of 384 people of graduates who registered. Working rate is lowest for those who suffer from a hearing disabilities which is $50.0 \%$. Most of them get job vacancy announcement information through a friend or family, internet and the offer from employers while undergoing industrial training. The position that normally grabbed by them is a clerk, teacher, lecturer, executive, account assistant or administrative assistant.

Based on previous studies, several factors have been identified as a major driver that greatly influenced the participation of Person with physical Disabilities (PWD) in the employment of technical and vocational skills. Financial security, job security, social needs and the need to be appreciated as well as appreciate become factors that motivate this group to engage in technical and vocational skills employment [13]. [14] also found them motivated to work because of employer acceptance, social needs, guarantee income, self-esteem need, being appreciated and given the facilities in the workplace. Since money is a great power that very affecting human life, it has become popular choices in the career of an individual.

There are several factors that influencing People with Physical Disabilities (PWD) blocked from engaging in employment sector of technical and vocational skills. These factors are divided into two that are internal and external factors. Internal factors that influence many of their weaknesses to compete in order to get jobs which is the attitude, interest, type of disability, working experience, technical skills and generic skills. Some external factors which restrict the opportunity for this group to be involved in the working area are employers, curriculum, workplace environment, trainers, parents and families.

Development of equal rights and employment opportunities for disabled groups identified has not been adequate although a lot of effort made by the Government to help them in building a better life with the community [15]. They indicate that the level of career selection constraints this special batch is at a high level because of the constraints of facilities in the workplace, lack of skills in the field of endeavour, less independent attitude, skills that followed during the study, not in line with the industry and family obstacles.

\section{MEthodology}

The study designed used quantitative survey using a questionnaire as a data collection tool. Application of Rasch Measurement Model in a study can facilitate measurement and result in a more efficient, reliable and valid [16]. According to [17], diagnosis items through Rasch measurement model can produce quality instruments. In carrying out the actual survey, data were collected quantitative by using a questionnaire. The questionnaire can be used in the study to obtain a more 
consistent answer [18]. Findings were analysed by using Winsteps software to generate value to answer issues that have formed.

The questionnaire used in this study include four constructs that are part A, part B, part C and part D. Part A intended to obtain information about the background of the respondents in terms of gender, race, age, marital status and education level. Part B consists of 25 items developed to get feedback on the factors that led to the involvement of Persons with Disabilities (PWD) in the employment of technical and vocational skills. Section $\mathrm{C}$ and $\mathrm{D}$ respectively contains 25 items and developed to obtain feedback on internal and external factors that prevent this special participation to enter the working world.

Researchers do this pilot study with distributing the questionnaire to 30 respondents drawn from a population study. The respondent consists of disabled trainees underwent technical and vocational skills training in Industrial Training Centre of Bangi. They were given a questionnaire containing 75 items Likert scale. The results from this pilot study analyzed using software Winsteps version 3.69.1.11 using Rasch measurement model approaches. Researchers examining the functionality of items in terms of reliability and separation of the items-respondents, polarity and the suitability of the item as well as a standardised residual correlation value. Before the pilot study conducted, aspects of the face and content validity are determined in advance. In this study data analyzed using quantitative using Winsteps software version 3.69.1.11 with Rasch measurement model approach fully. This model formed because of consideration to take into account the capability or the ability of each of the respondents answered the survey, test or instrument [19].

Samples involved in this study was Person with physical Disabilities (PWD) trainee that undergo training skills in Industrial Training Centre of Bangi. The amount of the population involved a total of 97 people and researchers take 30 people to be used as samples for carrying out the pilot study. From the total remaining population of 67 people and researchers using the population as samples. The purposive sampling method used in this study because the researchers have set the characteristics of respondents who would like to be reviewed and fixed the number of respondents [20]. The characteristics of the respondents are based on the conditions that enable them to get a job after completing the training that is reading and writing skills as well as aged 14 years and above.

\section{DATA ANALYSIS}

A. First research question: what is the dominant factor that drives the involvement of Person with physical Disabilities $(P W D)$ in technical and vocational skills employment?

To answer this question of this study, researchers conducted the analysis using the Item measures to obtain the value of the mean score. The value of the mean score obtained later had to be interpreted according to the levels that outlined by [21]. (i) Through the analysis found the value of the mean score for each item is to be at a high level between the range of 3.68 to 5.00. The value of total mean score is also the encouragement factor is at a high level of 4.39. This shows the encouragement factors very influencing involvement of Person with physical Disabled (PWD) in employment for the technical and vocational skills field.

Analysis for each construct found influence salaries are at the highest level with a mean score of 4.47 , while the lowest mean score was for constructs desire to socialize which is 4.24. Furthermore, analysis of the mean score for each item found items A13 and A14 are the highest scores at level respectively is 4.51 and 4.52. Both items contain constructs desire for independent, received by the community and feel needed. While the lowest mean score recorded by item A11 which is in constructs desire socialize at 4.10. The results of this analysis showed salary is dominant in propelling Person with physical Disabilities (PWD) in technical and vocational skills job with the highest mean scores 4.47 . This was followed by the desire of independent living (mean score 4.45), job security (mean score 4.38), the workplace (mean score 4.37) and the desire to socialize (mean score 4.24).

B. Second research question: what are the most dominant internal factors that prevent the participation of Person with physical Disabilities (PWD) in physical and vocational-technical skills employment?

Through the analysis conducted, it was discovered the value of the mean score for each item at a moderated level range between 2.34 to 3.67 . The overall mean score value for barrier factors internally is also at the medium level that is 2.76. This shows the internal factors prevent the participation of Person with physical Disabilities (PWD) in technical and vocational skills employment are not too strong influence rather than encouragement factors.

Analysis for each construct found that work experience influence recorded the highest score mean of 3.36 while the lowest mean score was for thought constructs that are 2.48. Further analysis of the mean score for each item found items $\mathrm{B} 30$ is most high that is 3.48 in working experience constructs. Mean score at the lowest level recorded by the item B20 and $\mathrm{B} 21$ respectively to the value of 2.242 .28 within the thought constructs. Overall this analysis indicates that work experience is the most dominant internal factors that prevent the participation of Person with physical Disabilities (PWD) in vocational-technical skills employment with the highest mean scores 3.36. This was followed by inability to factor (mean score 3.33), technical skill factor (mean score 3.01), soft skills factor (mean score 2.70) and thoughts factor (mean score 2.48).

\section{Third research question: what are the most dominant external factors that prevent the participation of Person with physical Disabilities (PWD) in technical and vocational skills employment? \\ Through the analysis conducted, it is found that the value of the mean score for each item is at moderated range level between 2.34 to 3.67 . The overall mean score value for the barrier in external factors also are at the medium level which is 2.95. This shows the external factors that prevent the participation of Person with physical Disabilities (PWD) in}


physical technical and vocational skills employment are not higher influence rather than encouragement factors.

Analysis for each construct found that employers factor registered as the highest mean score of 3.13 while the lowest mean score was for parental constructs which are 2.50. Further analysis of the mean score for each item detected that items C54 is highest at 3.28 in dissemination information constructs. The lowest level mean score recorded by the 2.24 in C42 items which were in the parental constructs. Overall, this analysis found that the employer is the most dominant external factors that prevent the participation of Person with physical Disabilities (PWD) in technical and vocational skills employment with the highest mean score value which is 3.13. This was followed by the salary factor (mean score 3.03), workplace and self-employed (mean score 3.01), the dissemination information (mean score 2.95) and parents (mean score 2.50).

\section{The fourth research question: is there a difference between} the perception of gender against the involvement of Persons with Physical Disabilities (PWD) in technical and vocational skills employment?

To answer this question of this study, researchers conducted an analysis of Differential Group Functioning (DGF) for seeing the value of $\mathrm{p}$ and $\mathrm{t}(\mathrm{p}<0.05, \mathrm{t}>2.00)$ to determine whether there is a significant difference in perception of gender. Analysis has been conducted in the study followed research constructs which Item CLASS A representing motivation factor, $\mathrm{B}$ represents the internal obstacle factors and $\mathrm{C}$ represent external obstacles factors. If the value of $\mathrm{p}$ is less than 0.05 and $\mathrm{t}$ more than 2.00, then there are significant differences between genders for each construct. Positive values $(+)$ in the value $t$ indicate that a group is difficult to agree in reply constructs provided, while a negative value (-) on the value of $t$ indicates that a group is easy to agree upon answering constructs provided.

It was found that only constructs A and B has a value of $\mathrm{p}<$ 0.05 and $t>2.00$. For the encouragement constructs factor, male respondents more difficult to agree that female respondent, while the internal obstacle factor constructs showed male respondents easier to agree than female respondents. For the external obstacle factors, in turn, constructs found that no significant difference between male and female respondents in answering constructs provided, but female respondents are more likely to agree than male respondents.

Next, the analysis of Differential Item Functioning (DIF) carried out for identifying the differences between the perception of gender for each item found in part B, C and D questionnaire. For encouragement constructs obtained most items have no significant difference where the value of $t$ is less than 2.00 and the value of $p$ is above 0 . Only four items showed the significant difference that is A1, A3, A6 and A14. All four of these items show the index positive for male respondents, which means that male respondents hard to agree with the items compared to female respondents. The study found that there was no significant difference in perception between male and female respondents against the factors that motivate their participation in technical and vocational skills jobs

Result analysis for internal barrier constructs also showed most items have no significant difference where the value of $t$ is less than 2.00 and the value of $p$ is more than 0.05 . The analysis found only three items showed the significant difference that is item B22, B27 and B35 ( $>2.00, \mathrm{p}<0.05)$. The index is negative at all three of these items show male respondents were likely to easily agree upon female respondents compared to answer the items on the questionnaire distributed. Results analysis found there was no significant difference in perception between male and female respondents on the internal factors that prevent their participation in technical and vocational skills.

Result analysis for external barriers also constructs the same result, namely, most items have no significant difference where the value of $t$ is less than 2.00 and the value of $p$ is more than 0.05 . Found just one item shows a significant difference that is item C52 ( $\mathrm{t}>2.00, \mathrm{p}<0.05)$. A positive index item this shows male respondents are more difficult to agree that female respondent during the answer items on the questionnaire distributed. The result of this analysis shows that there is a significant difference in perception between male and female respondents against external factors that prevent their participation in technical and vocational skills.

\section{DISCUSSION}

A. Summary of findings 1: Identify dominates factor that drives Person with physical Disabilities (PWD) involvement in technical and vocational skills employment Findings the study found salary is a dominant factor in pushing the disabled to participate in employment. They strongly agree that salaries allow them to buy daily necessities, getting side needs such as vehicles, enabling them to live in a comfortable house and can be saved as savings for the future. This is in line with the opinion of [22] that says salary or remuneration is the main factor of human work and lucrative salary attracts people to apply for the job position. Since money is a great power with very affecting human life, it has become popular choices in the career of an individual. These special groups are no exception and they choose to work because it needs money to support life.

The next finding state that most of the respondents strongly agree that workplace which have friendly Person with Disabilities (PWD) values practice had a strong influence on their participation in employment. This case clearly shows the security features, user-friendly facilities and a comfortable working environment led this cluster to work. The study is in line with the views of [13] who argue that these special clusters require a workplace atmosphere that is safe and appropriate to the type of their disability. [23] also agree that the value of respect is a workplace diversity with the career for the special. Failure to adapt to the environment in the workplace can cause many Person with Disabilities (PWD) withdrawing from the working world. 
The further findings found that most respondents strongly agree on elements of desire independent living, feeling essential, received by the community and job security for the future motivates them to work. This is in line with the views of [24] which say that the disabled need a guarantee of the future, expecting themselves socially acceptable, needed and wanted to be independent. Therefore, the acceptance of the employer of this group is important in providing a positive impression for them to work comfortably. Amenities and facilities provided also convincing them to work with more intensely felt their participation at work get acknowledged from the employer. It also allows them more independent and wants to compete with the better to gain recognition and praise from people around.

\section{B. Summary of findings 2: Identify the most dominant internal} factors that prevent the participation of Person with physical Disabilities (PWD) in technical and vocational skills employment

Although exposure on job with industrial training had been given before completing training, respondents still considered lack of working experience and cause application to get work difficult accepted by employers. At the outset of the opinion these problems should be overcome because of the training and the skills practiced by them will be wasted if the chance to get limited work or hard to come by. Considering that government had allocated financial resources for the Person with Disabilities (PWD) run their own enterprises, training centres must provide adequate training and guidance to be able to stand on their feet for the self-employed. This will help them not to be completely dependent on government or private sector employers in a position that possibility does not match skills.

The further findings indicate most of the respondents agree that physical disability causes them hard to get jobs. The majority opinion of job opportunities is limited because of their disability. Studies conducted on the operators of small and medium enterprises also found employers only accept Person with Disabilities (PWD) only on disable type of vision and hearing as an employee [25]. This clearly shows the occurrence of discrimination that causes physically disabled people marginalised from obtaining employment. Acceptance of employees with disabilities are often evaluated in terms of their ability to carry out a work not based on the skills and creativity is owned by them.

The findings of a study on the internal obstacle factors for most of the respondents disagree that they had a negative thought for some of the items in the questionnaire. Disabled people believe they can be independent and manage personal needs without the help of others. This may be because they have already received training from their parents or training centre. However, some respondents remain hesitant and less confident to deal with community especially if they were alone and not with individuals who are known. The findings of this study are consistent with previous studies which [8] found that disabled people are not only difficult to achieve a good education, but they tend to adopt the concept of negative against themselves, afraid and not confidence.
C. Summary of findings 3: Identify the most dominant external factors that prevent the participation of Person with physical Disabilities (PWD) in technical and vocational skills employment

The third finding detected that the employer is the most dominant external factors that prevent this special batch of engaging in employment. Most of the respondents agree that the employer was sceptical and reluctant to take the risk to accept them as an employee. This group also agreed that the employer will underestimate their abilities and employ them will give distress such as accidents at work. This is in line with findings by [26], which found employers reluctant to take Person with Disabilities (PWD) as employees because had to make adaptations in physical work, concerned productivity would decrease, increase the cost of insurance and should be thinking about compensation, health, as well as worker safety.

The next findings found that minimal salary deals caused disabled people tend to choose self-employed. The job gave to them only the low-class such as labour, clerk and cleaner. Salaries were at minimal levels and not commensurate with skills. The findings are in line with findings by [27] which sets out of $60.0 \%$ Person with Disabilities (PWD) in terms of sight choose for self-employed as flexible work time, can make more money, a comfortable working environment, free to express your ideas and can build better skills.

Results of the next findings found respondents less agree on negative parental attitudes contribute to the lack of their participation in the employment sector. This situation shows most parents these days are more positive and open in addressing the issue of children with disabilities. This is not in line with studies conducted by [7] who argue that too negative attitude as parents protect and give false hopes by stating their children can heal someday make those less fortunate this is prevented from engaging in employment.

\section{Summary of findings 4: Identify the differences between the} perception of gender against the involvement of Person with physical Disabilities (PWD) in technical and vocational skills employment

The fourth study findings found that there are differences between perception of male and female trainees against factors that motivate their participation in employment. In addition, Person with Disabilities (PWD) men trainees tend to hardly agree that salaries, workplace and desire independent living is the factors that motivate them to work in comparison with female trainees. Constructs the internal obstacles also shows the existence of differences in perception between male and female trainees against their participation in employment. For this, the male constructs the trainees found it easier to agree that female trainee, for the negative factors of thought and communication skills.

The external obstacle factors for overall did not show differences in perception between the gender. However, the result for each item can be seen have significant differences between the gender for work environment factors. Male trainees tend to difficult consents to this factor. Findings of this study are consistent with statements made by [28]. Attitude influence and demographics can affect participation and 
productivity of work produced by an individual as in terms of gender, age, marital status and length of service. [29] on the other hand specifies the demographic characteristics such as gender and academic qualifications are very important in the selection of an employee and can give rise to the issue of discrimination against women.

However, overall both male and female respondents agree that the existence of factors that motivate and factors that hinder their participation in employment. There are no significant differences between the gender. Salary is the most dominant factor in motivating them to work, while the factors the employer and work experience are found to prevent them to engage in employment. Nature on the male and female is normal that makes each of them has strengths and weaknesses of each.Finally, the researcher hopes that this study can help PWD to be more positive for job opportunities and change the employer's perception so that they are more open to accepting them as the employees.

\section{CONCLUSION}

As a result of research performed, encouragement factor was found to be higher significant influence over the involvement of Persons with Disabilities (PWD) in technical and vocational skills employment. However, the constraints in terms of Interior and exterior also affect the participation of disabled people in employment although only at a moderate level. In the first study analysis results showed that salary is the dominant factor led to the involvement of Person with physical Disabilities (PWD) in jobs. This shows the appropriate amount of salary should be offered to workers with disabilities because as usual they also have human needs and requirements that must be met.

The second objective of this study found that working experience is a factor of internal barriers are most dominant in blocking this special inclusion in the working world. Work experience is not a new issue but is one of the main criteria which are assessed during the get work. Thus, this group needs to be exposed to nature of employment in detail to ensure that they are not blocked in obtaining Kerajaan. For the third objective of the study, the employer is the most external obstacles factor is dominant in restricting the participation of Persons with Disabilities (PWD) in employment. Perceptions and attitudes of employers less conscious cause cluster group continued to be marginalised and did not get a place in the industry.

For the last research objective on the perception of differences between gender for whole constructs show that there is a different view between female and male trainee in encouragement factor and internal constraints factor. For the difference in perception between the gender in respect of each item, found most items did not show significant differences. Just a few items from B, C and D show the difference and it has been described by researchers. These differences may be influenced by the nature of the differences between men and women, life experience, the value of self-owned and different demographic factors. As a conclusion, the involvement of Person with physical Disabilities (PWD) in technical and vocational skills employment mostly influenced by several factors motivation factors and barriers. However, these factors may give different results for other disabled groups.

The study has been explained in details about motivation and barriers factors to the participation of Person with physical Disabilities (PWD) in technical and vocational skills employment. It is hoped that this research will provide information and benefits to readers and all related parties. Hopefully, it can also improve the quality of related technical and vocational skills training to help disabled people obtain jobs and better earnings in the future. It is also an effort to give encouragement to this special batch so that they will be more confidence to enter the working world and live with the community. Opportunity should be given to them for this special physical disability because they experiencing physical limitations. Their intelligence and creativity should not be taken as inconsequential because they might be better than ordinary humans have now.

\section{REFERENCES}

[1] Sulaiman, R. (2008). Faktor-Faktor Pendorong Golongan Orang Kurang Upaya (OKU) Bekerja di JARO (Johor Area Rehabilition Organisation). Johor Bahru: Penerbitan Universiti Teknologi Malaysia.

[2] Arifin, Z. (2006). Kerjaya untuk Orang Kurang Upaya. Kuala Lumpur: PTS Professional

[3] Jabatan Kebajikan Masyarakat. (2008). Profail Statistic 2008. Kuala Lumpur: Jabatan Kebajikan Masyarakat.

[4[ Pekeliling Perkhidmatan (2008). Pelaksanaan Dasar Satu Peratus Peluang Pekerjaan Dalam Perkhidmatan Awam Kepada Orang Kurang Upaya. Bil. 3. Jabatan Perkhidmatan Awam.

[5] Kementerian Pengajian Tinggi (2011). Profil dan Maklumat Pekerjaan Graduan Orang Kurang Upaya dlm. Laporan Kajian Pengesanan Graduan. SKPG II: 143-171.

[6] Prasai, M. (2010). Relevant Vocational Training For The Persons With Disabilities In Nepal. Technical \& Vocational Education and Training Development Journal. 1-7.

[7] Wagiran. (2007). Inovasi Pembelajaran dan Penilaian dalam Penyiapan Tenaga Kerja era Global. Jurnal Pendidikan Teknologi dan Kejuruan. Vol. 16 (1). 41-55.

[8] Lee, M. N., Abdullah, Y. \& See, C. M. (2011). Empolyment of People With Disabilities In Malaysia: Drivers and Inhibitors. International Journal of Special Education. 26(1): 112-124.

[9] Saari, Z. (2005). Keberkesanan Pendidikan serta Latihan Teknik \& Vokasional di Kalangan Golongan Orang Kurang Upaya dalam Melahirkan Keperluan Sumber Guna Tenaga Negara. Universiti Teknologi Malaysia: Tesis Sarjana.

[10] Jabatan Kebajikan Masyarakat. (2011). Bahagian B (10): Pendaftaran Orang Kurang Upaya. Dicapai pada Januari 4, 2013, dari Jabatan Kebajikan Masyarakat Malaysia: http://www.jkm.gov.my/index.php?option=com_jdownloads\&Itemid=31 $4 \&$ task $=$ viewcategory $\&$ catid $=41 \&$ site $=2 \&$ start $=10 \&$ lang $=\mathrm{ms}$

[11] Bank Dunia (2010). Disability and The Millennium Development Goals. Dicapai pada Disember 29, 2012 dari http://web.worldbank.org/WBSITE/EXTERNAL /TOPICS/EXTSOCIAL-PROTECTION/

EXTDISABILITY/0,,contentMDK: $21162907 \sim$ menuPK:3265756 page PK:210058 piPK:210062 theSitePK:282699,00.html

[12] Toran, H., Muhamad, T. A., Mohd Yasin, M. H., Tahar, M. M. \& Hamzah, N. H. (2010). Pengetahuan dan Sikap Rakan Sebaya Terhadap Pelajar Kurang Upaya Di Sebuah IPTA Di Malaysia. AJLTHE. 2(2): 21 32. 
[13] Mohd Said, M. R. \& Sulaiman, R. (2009). Faktor-faktor Yang Mendorong Orang Kurang Upaya (OKU) Bekerja Di JARO (Johor Area Rehabilitation Organisation). Johor Bahru: UTM.

[14] Uzir, M., Royo, M. A. \& Nasir, Z. (2010). Faktor-Faktor Pendorong Orang Kurang Upaya Bekerja Di Bengkel Daya Klang, Selangor. pp. 110. (Unpublished).

[15] Lau, P. L., Muhamad, A. S. \& Chew, F. P. (2011). Peranan Kaunselor dan Perkhidmatan Kaunseling Kerjaya Bagi Orang Kurang Upaya. ATIKAN. 1(2): 233-246.

[16] Abdul Aziz, A. (2010). Rasch Model Fundamentals: Scale Construct and Measurement Structure. Kuala Lumpur: Integrated Advanced Planning Sdn. Bhd.

[17] Wright, J. D. \& Stone, J. E. (2010). Misbehavioral Economics: The Case Against Behavioral Antitrust. George Mason Law \& Economics Research Paper. 11-23.

[18] Konting, M. M. (2004). Kaedah Penyelidikan Pendidikan. Kuala Lumpur: Dewan Bahasa dan Pustaka.

[19] Rasch, G. (1980). Probalistic models for some intelligence and attainment tests. Chicago: The University of Chicago Press

[20] Bernard, H. R. (2000). Social research method: Qualitative and quantitative approaches. California: SAGE Publications

[21] Landell, K. (1997). Management by Menu. London: Wiley \& Soms Inc.

[22] Abdul Majid, A. H. (2004). Mengurus Sumber Manusia dan Sistem Gaji. Pahang: PTS Professional Publishing Sdn. Bhd. Akta Orang Kurang Upaya (OKU) (2008). http:// rehab -malaysia.org/wp-content/uploads/
2011/ 12/Akta-Orang-Kurang-Upaya-2008.pdf. Dicapai pada 4 Januari 2013.

[23] Gilbride, D., Stensrud, R. \& Vandergoot, D. (2003). Identification of The Characteristics of Work Environments and Employers Open To Hiring and Accomodating People With Disabilities. Rehabilitation Counselling Bulletin. 46(3): 130.

[24] Khoo, T. E. (2006). Pengharapan Pelatih OKU Terhadap Program Latihan Pemulihan Yang Dijalankan Di Pusat Pemulihan Dalam Komuniti (PDK) Jitra, Kedah. UTM Skudai: Tesis Sarjana Muda

[25] Shahari, R. \& Abd Latib, A. (2006). Tanggapan Usahawan Industri Kecil dan Sederhana (IKS) Kerepek Ubi dan Pisang Di Sekitar Batu Pahat Terhadap Kemampuan Golongan Orang Kurang Upaya (OKU) Untuk Bekerja Dalam Industri Mereka. Thesis Sarjana Muda: UTM

[26] Griffin, T. \& Nechvoglod, L. (2008). Vocational and Educational Training and People With Disability: A Review of The Research. Australia: NCVER.

[27] Samian, S. S. \& Buntat, Y. (2012). Self Employment: Perception Among Deaf Students In Malaysia Higher Education Through Workplace Experiences. 3rd International Conference On Business and Economic Research Proceeding. Pp. 1545-1556.

[28] Abdul Ghani Azmi, I. \& Wan Ahmad, W. S. (2008). Pengaruh Sikap dan Demografi Ke Atas Produktiviti Kerja Pensyarah Muslim: Kajian Di Universiti Malaya. Shariah Journal. 16(2): 321-244.

[29] Richards, G. A. (1988). Study of the recruitment of engineering apprentices in coventry. Ph.D Thesis, Warwick University. 